Working Paper No. 623, 2004

On the Static Efficiency of Secondary Bond Markets

by Lars Oxelheim and Michael Rafferty

IUI, The Research Institute of Industrial Economics

P.O. Box 5501

SE-114 85 Stockholm

Sweden 


\title{
On the Static Efficiency of Secondary Bond Markets
}

Lars Oxelheim, Lund Institute of Economic Research, and The Research Institute of Industrial Economic (IUI), Sweden

and

Michael Rafferty, School of Economics and Finance, University of Western Sydney, Australia and Baltic Financial Markets Group, University College of South Stockholm, Sweden

April 2004

\begin{abstract}
The major strand of finance literature understands market efficiency through the market's ability to process information into prices. Another strand of literature refers to the economists' usual sense of the word, i.e. that markets ensure that resources are allocated to their most profitable expected use, and provide services at the lowest cost. This paper, deploying the second definition, suggests a concept of static efficiency, and claims this can also be seen as a measure of market quality. The paper develops a measure of qualitative static efficiency for bond markets built on four indicators: transparency, number of maturities and issuers, spread, and liquidity. Indicators of market quality should be easily accessible, and permit international and intertemporal comparison. Using Nordic markets as case studies, we show that these markets became more efficient during the 1990's, but that transparency of efficiency remains a problem. A number of measurement problems with the static efficiency indicators are discussed, as well as interdependence issues. The paper concludes with comments on future applications of the static efficiency measure.
\end{abstract}

Key words: efficiency, transparency, market liquidity, bond markets.

JEL: D82, E44, G15, G18, G28, G38

Forthcoming in Journal of Multinational Financial Management 


\section{On the Static Efficiency of Secondary Bond Markets}

\section{Introduction}

Recent crises in emerging markets and scandals in developed capital markets have raised issues about the transparency and quality of markets. In finance, such issues have typically been analyzed within the broader context of market efficiency. Efficiency in the context of capital markets has been defined in many ways, but a standard way has been to define it in terms of what sort of information is available to market participants, and how they handle that information. According to this view, an efficient bond market is one where bond prices accurately reflect all available information, and quickly adjusts to new information. It is assumed within the efficient markets hypothesis, that market participants rationally formulate their bond buying and selling decisions based on available information about bond prices and their relevant determinants. ${ }^{1}$

But markets are also economic institutions that require resources and economic agents. Efficient markets in this wider economic sense are involved in allocating resources to their most profitable use and in cost effective ways. ${ }^{2}$ This paper is concerned with one aspect of the wider economic sense of efficiency through the concept of static efficiency in the context of secondary bond markets. The concept of static efficiency is aimed at improving the international and intertemporal comparability of bond market quality. The degree of comparability between markets and over time is currently very poor. It is now well known that there is often a trade-off to be made between different qualitative characteristics, and no single indicator of qualitative efficiency can adequately reflect market quality. We therefore suggest a composite measure of static efficiency consisting of four qualitative indicators: transparency, number of maturities and issuers, spread, and liquidity to depict a bond market's main structural or operational features. 
Burns (1979) earlier suggested the need for a composite measure of capital market efficiency, and proposed the concept of operational efficiency employing three indicators; liquidity, orderliness, and organizational quality. This measure was, however, developed primarily for equity markets and does not translate easily to bond markets. The concept of static efficiency might be usefully deployed to bond markets for some questions of interest to market participants and researchers, particularly where qualitative aspects of efficiency are considered. The relevant concept employed should then depend on the particular question/s being asked.

The indicators of static efficiency are seen here as reflecting the quality of a secondary market. ${ }^{3}$ While this dimension to market efficiency is often seen as most important in times when markets are subject to shocks or discontinuities (such as October 1987, the Russian currency crisis, the Asian financial crisis and September 11, 2001), knowledge about static efficiency is also important to institutional investors, and to corporate issuers. A choice will sometimes have to be made between say bonds offering the same payoff in markets similar in all respects except in one or more of the qualitative aspects addressed here.

Investors and issuers need easily accessible information about the quality of different secondary markets. Currently that information is not available in a way that permits international or often even inter-temporal comparison of secondary bond markets. The research issue of this paper is to develop a measure of market quality and to address the implementation problems involving how to make the measure, or at least the indicators it is built on, accessible and comparable across markets. Research on market quality has also rarely considered the relative importance of the fixed income market. This is largely because bond data is not easily collected (Sarig and Warga (1989), Goodhart and O’Hara (1997)). Financial researchers have long been plagued by the paucity of data on bonds relative to stocks. 
In the empirical part of the paper, bond markets in Nordic countries are used as a regional casestudy. A study of markets in the Nordic region is useful, because it allows a comparison of similar capital markets that have different regulatory approaches. The Nordic markets are characterized by a transformation from thin, illiquid markets in the 1960s to fairly well functioning markets by the mid-1990's (Oxelheim, 1996), a development has continued into the beginning of the 2000's.

The paper begins by briefly considering the relationship between informational efficiency and allocative/resource efficiency. It then introduces a concept of static efficiency, and suggests a set of indicators of a well functioning secondary market that would be consistent with such a definition. The values derived for indicators of static efficiency are analyzed for the case of bond markets in the Nordic countries. This is followed by a consideration of the major problems related to the measurement of static efficiency. The paper concludes with comments on future extensions and applications of the static efficiency indicator.

\section{Market Efficiency - Information, Allocative and Resource Perspectives}

The efficient markets hypothesis is a concept of informational efficiency, and refers to the market's ability to process information into prices. It is usually thought that there is a connection between informational efficiency and the more standard economic concepts of allocative/resource efficiency. Indeed, an important economic proposition that emerges from the (semi-strong) informational efficiency hypothesis is that prices in efficient markets adjust quickly to reflect changing market 'fundamentals'.

Following the seminal work of Grossman and Stiglitz (1980), there has also been a growing debate about the analytical and empirical status of the efficient markets paradigm. Some researchers have also observed that even in highly liquid markets, anomalies are still detectable that contradict weak form efficiency. A significant strand of research in contemporary finance has even emerged 
based on a proposition of inefficient markets. Some economists have gone so far as to question whether informationally efficient markets are necessarily efficient in the wider economic sense (Stiglitz 1981). In an analytically confronting environment opinion is predictably divided.

This paper is concerned with a set of allocational/resource efficiency issues, and proposes a concept of static efficiency for cross border and inter-temporal comparison of market quality. To reiterate, a market that is efficient as regards the processing of information into prices may or may not necessarily be so in the economists' usual sense of resource efficiency. The concept of static efficiency introduced here is closer to economists' usual understanding of the term of resource efficiency, that is, provision of services at the lowest cost in terms of the resources employed. In the case of information needed to measure static efficiency, we then scrutinize the problems that prevent an equalization of supply and demand.

\section{Static Efficiency and indicators of well-functioning secondary markets}

In this section, the Nordic markets are used to highlight the value of the different indicators in assessing the quality of secondary bond markets, that is, how well these markets function. The static efficiency of secondary bond markets is of importance to bond investors and issuers for several reasons. Empirical evidence suggests that investors are prepared to pay a premium for trading in a market where their investment can be easily liquidated and where transparency and investor protection is greater (LaPorta et.al. 2000). That is, different 'efficient' prices for very similar assets may arise on the basis of these qualitative market differences Boudoukh and Whitelaw (1993).

Important indicators of a well-functioning secondary bond market can be listed, and classified as indicators of static or dynamic efficiency. The following four static indicators can be identified: a high degree of transparency, a multiplicity of maturities and issuers, a low spread, as well as high and continuous liquidity. We suggest these indicators as the pillars of a static efficiency measure. In 
addition to indicators of static efficiency, an efficient market is also one with a high level of adaptability to innovation, reflecting the dynamic functioning of the market (dynamic efficiency). This latter aspect is, however, developed in another paper (Oxelheim and Rafferty, 2003).

In addition to these indicators, problems of state intervention and regulation should also be noted. It is understood that a market that is too heavily (or poorly) regulated on the demand and supply sides and as regards prices, is not a "well-functioning market." Thus, the first prerequisite of a well-functioning market is that a "market" does in fact exist. That is, the forces behind demand and supply are actively engaged in price formation. This does not mean a completely deregulated market. On the contrary, it is now more widely appreciated (especially in the wake of policies employed in early transition phase of some former Soviet states) that some essential state regulation and involvement (a 'minimum set') is required to guarantee the structure and efficiency of markets. As LaPorta et.al. (2000: 29) concluded '...leaving financial markets alone is not a good way to encourage them'. Oxelheim (1996) found that a secondary market existed in Denmark as far back as the 1970s, and that such a market gradually emerged in Sweden after 1983, followed by similar developments in Norway and Finland. However, according to the stricter definition of a wellfunctioning market, that is, taking into account all types of controls over domestic or cross-border bond transactions, no such market existed before at least 1988 in Denmark, 1989 in Sweden and the early 1990s in Norway and Finland. Some restrictions in excess of the minimum set mentioned above still obtained in Finland and Norway in the mid-1990s, but by the end of the 1990's, bond markets in all the countries had attained 'maturity'.

For bond markets at a global level, benchmark market regulations are provided by the Association of International Bond Dealers (AIBD) and the International Securities Markets Association (ISMA) ${ }^{4}$, while Euroclear and Clearstream ${ }^{5}$ furnish the market with generally accepted 
settlement systems. Surprisingly, measures of operational efficiency of bond markets are very scant. In an important sense, an appropriate national and international regulatory approach needs qualitative and quantitative information of the sort developed in this paper.

\subsection{Transparency}

Having established the formation of secondary bond markets in these countries, we now proceed to consider the first indicator of their quality, namely the degree of transparency. This indicator, pin-pointed as one of the twin-principles of the GATS agreement of 1999, is another aspect of the financial infrastructure of crucial importance to the functioning of markets. The way in which trading is organized and information disseminated together constitute the transparency of a market. Some researchers have been concerned with differences in degrees of transparency between auction and dealer markets ${ }^{6}$, but few have looked at differences between geographical markets or tried to determine their relative attractiveness for issuers. Transparency research often examines the different changes in market microstructure and its effect on factors such as liquidity and informational efficiency. ${ }^{7}$ In this respect, Nordic secondary markets were not functioning particularly well until the end of the 1980s, when stricter listing systems and rules about the reporting of trading in bonds were introduced. In order to get hold of bearer bonds after the stricter listing requirements were introduced, for instance, governments made registration mandatory.

Table 1 shows that the dissemination of information gradually improved in all Nordic countries after the mid-1980s, with the introduction of electronic trading systems and better registration routines. Additionally, a new information system, Nordic Value Feed, was introduced in the early 1990s to provide information about the prices and trading volumes registered on all four Nordic stock markets. The trend towards the decentralization of trade from stock exchanges to OTC markets required stricter reporting requirements so that transparency could be maintained. 
Consequently, during the 1990's, all the Nordic countries established special institutions for the registration of trading. Even in the late-1990s, however, information about trading in Nordic bonds outside the Nordic region still lacked a formal registration procedure.

Another aspect of transparency concerns listing practices. In 1991, the number of bonds listed on the Nordic stock exchanges was 2,315 (almost 100 per cent of all issues) on the Copenhagen Stock Exchange, 628 (about 50 per cent) at the Helsinki Stock Exchange; 938 (about two-thirds) on the Oslo Stock Exchange; and 1,262 (close to 100 percent) on the Stockholm Stock Exchange. To put this in a global perspective, the highest number of listed bonds on the largest global bond markets at that time was 12,679, on the German Stock Exchange, while figures for New York, Tokyo and Osaka, and London Exchanges were 2,727, 2,546, and 4,606 respectively. ${ }^{8}$ In the late1990 's, the pattern of listing still differed considerably from country to country, ranging from 100 per cent of all issues in some countries to only a fraction of the total in others. In the Nordic area, the number of listings on Helsinki and Oslo decreased, whereas the number remained fairly stable for the other two exchanges. On the largest government bond market, the US market, all bonds were listed on the New York Stock Exchange, while on the second largest government bond market, the Japanese market, only 10-year and 20-year bond issues were listed. However, on both these markets only a small fraction of trade takes place on the organized exchange. The existence of specialized brokers engaged in marrying the bids and offers of members of the dealing community and an efficient screen price service, is assumed to ensure price transparency. ${ }^{9}$

The organization of bond trading gives a fair picture of listing practices and transparency. In the early 1990s, the share of the total outstanding stock of bonds traded on stock exchanges differed between the Nordic countries. The smallest share was found in the Helsinki Stock Exchange, where the biggest share of trading took place on the OTC market. Trade in Helibor ${ }^{10}$ 
bank bonds predominated. Five major banks acted as market makers, and the inter-bank market between these banks was the most active secondary market. The largest share of exchange trade was found in the Danish market, with almost all trading taking place through the exchange. In the early 1990s, listed government bonds predominated, although the outstanding stocks of mortgage bonds were bigger. In Norway, many issues were small and seldom traded on the secondary market. It was often a case of private sector issues in the range of NOK 100-200 million or issues by municipalities in the region of NOK 200-400 million. Only about 50 issues in Norway exceeded NOK 1 billion, and few bonds were very frequently traded. Almost fourfifths of the turnover in Norway was registered for mortgage bonds. On the Stockholm Exchange, about one-third of listed issues, corresponding to slightly less than half the nominal value of the domestic outstanding stock of bonds, were actively traded. Furthermore, as in the Danish market, trading in listed government bonds and notes predominated.

In the late 1990s, trading practices still differed across the Nordic region. Nevertheless, a common feature between them is that the most traded bonds involves some sort of market-maker arrangements that guarantees two-way prices. Usually, this market making involves the Nordic central banks assuming some or this entire role. The share of total bond trading on the stock exchange has shown a tendency to fall, but the decline in transparency thus caused was compensated to some extent by improved information systems.

\subsection{Multiplicity of Maturities}

A second indicator of a well-functioning market is the multiplicity of alternative maturities and issuers in the supply of bonds. This multiplicity involves a trade-off between an extra yield premium to investors that do not find the desired issuer or maturity structure, and the size and liquidity of each individual bond issue. ${ }^{11}$ In the early 1990s, the Danish market, with a broad 
spectrum of maturities and large number of issues, could have been regarded as the best. Nonetheless, maturities in the Danish market fell well short of the US treasury market with its heavy trading in 8 slices - 2, 3, 4, 5, 7, 10, 20 and 30-year bonds. The negative side of the Danish market, relative to the other Nordic markets, was the more or less negligible amount of bonds issued directly on the domestic market by the Danish non-financial corporate sector. By the end of the 1990s, all the Nordic markets had improved in terms of multiplicity. Corporate bond issues were more frequent in all the markets and most frequent in the Swedish market. About 40 Swedish companies had raised money through bond issues on that market, mostly through medium term note (MTN) programs. However, the amount borrowed by non-financial companies was still less than 10 percent of the total amount raised in 1999.

Looking into the multiplicity of maturities opens up some definitional questions. What should actually be seen as the national secondary bond market? Should it be the market place for issues with the prefix "domestic", that is, a domestic issuer, domestic trading, domestic currency etc.? In our view, the only relevant requirement should be that the bond should be traded at that particular market place, irrespective of the designation of the participant or denomination of the bond. Hence domestic issues by non-residents should also be considered part of the national market. Notwithstanding this, the amounts raised by non-resident borrowers in the Nordic markets have so far been negligible. ${ }^{12}$ During the second half of the 1990 s some non-resident issues were reported for the Norwegian bond market, but even here the gross issues of bearer bonds by non-resident borrowers in 1998 amounted to less than $1 \%$ of the total amount raised. The introduction of the Euro from the first of January 1999 (and its adoption by Finland) suggests that the national currency should not be used in defining the "national" market. 
Moreover, in discussing multiplicity, the figures for each category should be weighed with its trade frequency to provide information about market quality.

\subsection{Spread}

The third indicator of the efficiency of a secondary bond market is a low spread. ${ }^{13}$ Differences in this respect reflect inefficiencies, and are an expression of competitive pressures on the market. Spreads typically vary with maturity, size of deal, type of issue and minimum tick size, and with market structure characteristics (O'Hara 2001). When markets are to be compared in terms of spread, either the spread of representative species of similar issues or some form of average spread can thus be used. A low representative spread is an indicator of a cost-efficient and competitive market. Previous research has addressed the effect of tick size on the quality of a given market, especially in terms of its effect on liquidity (Chan and Hwang 1998). Other research has also discussed differences in spreads in different markets, such as corporate/government or dealer/call/contingent (Chakravarty and Sarkar 1999, and Theissen 1998). In the early 1990s, in terms of the representative bid-ask, the Nordic countries fell into two groups. One group, consisting of Denmark and Sweden, had a low spread approaching the size of the spread on the domestic US bond market, while the other, consisting of Finland and Norway, had an average spread in the range of 5-10 basis points higher, expressed as a percentage of the amount traded. By the end of the 1990s, however, all four countries were in the low spread category.

Another way of measuring spread is to disaggregate spread into different liquidity sectors, since some issued bonds are not intended to be traded on secondary markets, while others are highly traded. Consequently quoted spreads may vary widely and simply averaging these may be 
misleading. Unfortunately, contemporary data is not available to permit disaggregated comparisons. ${ }^{14}$

\subsection{Liquidity}

The fourth and perhaps most significant indication that a secondary bond market is functioning well is a high and sustainable level of liquidity. ${ }^{15}$ In market microstructure research, liquidity is often described as the tightness, the resiliency or the depth of a given market. ${ }^{16}$ Here we use depth as measured by the ratio between turnover and stock of bonds. Note that tightness is most often measured as the bid-ask spread and therefore partly discussed in the previous part of this article. Attempts to rank different geographical markets relative to quality, based on liquidity, measures have been rare. A BIS report on market liquidity (1999) compared government fixed-income liquidity measures for five different countries. However, the stability of liquidity deserves further consideration since it provides information about the continuity of the market and how it might function under different stresses. Another way of measuring the depth of liquidity would be to measure the sensitivity of price to changes in volume. Unfortunately, series of such measures are rarely published even though they provide important signals about a market and its vulnerability. Among other things, such a stability measure would signal the degree of risk inherent in a market, that is, the risk of its breakdown in a situation of general financial distress. ${ }^{17}$

\section{Difficulties in measuring quality of secondary markets - transparency issues}

In addition to the identification of the relevant indicators of our measure of market quality, the major part of the research issue is to discuss problems related to making such a measure easily accessible on an international and inter-temporal basis. The measure should lend itself to inter-temporal as well as international comparisons. Liquidity measures constitute an important 
part of the quality measure. However, it is difficult to find accessible liquidity (depth) measures that lend themselves to quality comparisons across markets. There are several problems with the data on liquidity measures that make interpretation or comparison across markets or over time problematic. In particular, three kinds of problems can be distinguished: one related to the numerator, one to the denominator, and a third connected with the process of putting these two together into a measure of liquidity. In the search for consistency in approach, a large number of empirical problems present themselves. What we are aiming for here is the development of an internationally comparable measure of total market liquidity as the total turnover in all relevant market segments relative to the market value of all outstanding bonds (in these segments).

What, then, is meant by relevant market segments? Some bonds are not intended for extensive trade, which suggests that we could divide the outstanding stock of bonds into two parts - one tradeable and one non-tradeable - and then claim that the liquidity of the tradeable part is representative of the liquidity of the market. The tradeable part also acts as a price-setter for the other part of the market, consisting mainly of small issues, predominantly from private issuers. However, as soon as we introduce the concept of the relevant market segment, as opposed to the total market, we introduce discretion and face the problem of choosing an appropriate way of splitting the market in a way that allows for comparisons over time as well as across countries. Bearing this in mind, we continue our review of the statistical problems.

Let us start with problems connected with the denominator and the market valuation of a stock of bonds corresponding to the definition above. The first task is to define the set of bonds appropriate for consideration. This brings us to the problem of defining the total set of outstanding bonds, since not all bonds are registered. Assume that we solve the problem of identifying all missing non-registered bonds by defining our population as consisting of 
registered bonds only. The question then arises of whether to limit the relevant set to include listed bonds only, since in some markets information is only published for this set. Further, in some countries bond markets only provide information about top lists. A market's listing praxis, i.e. the listing requirements and the scope of the listing, is important and often add further problems to the search for consistency. Once a decision has been made about which definition of outstanding bonds to use, we face the problem of finding the market valuation of that stock. However, regardless of which definition is used, a good proxy for market valuation in the case of bonds is the nominal value of the outstanding stock of bonds. ${ }^{18}$

The next category of empirical problems is connected with the numerator and the way in which turnover is reported. An important issue here concerns double counting. For the user of international sources of statistics, double counting problems often arise in international comparisons. Another dilemma concerns the transactions that are included in the turnover figures. Many sources give turnover data that includes both spot and forward transactions, while others include spot transactions only. ${ }^{19}$ Unfortunately, this is not generally stressed sufficiently in the presentation of international turnover data. And even when the distinction is made, it is still difficult to transform the data in order to achieve comparability. In addition to the problem of the actual content of information, there is also the problem of differences in reporting requirements. Some countries impose reporting requirements on all financial institutions that deal in bonds, while others rely on voluntary reporting. ${ }^{20}$ The introduction of improved systems for the registration and reporting of trading activities could thus actually distort comparisons in the short-term. Once improvements have been made, however, international comparison should become more accurate. Finally, there is the problem of finding a correspondence between numerator and denominator, that is, matching a turnover figure for the numerator with the stock 
of bonds used in the denominator. We now consider the problems involved in measuring liquidity, by comparing the liquidity of the Nordic bond markets.

Table 2 shows that the turnover of bonds on the Nordic stock exchanges increased substantially from the 1970s. However, a large part of the increase reflects the development of better routines for listing and reporting bond trading. This applies particularly to the Danish increase in 1988; the Norwegian increase in 1987 and the dramatic Swedish upturn in 1985. In the case of Sweden since 1985, for instance, the figures for the Stockholm Stock Exchange also include dealing in government and mortgage bonds taking place outside the Stockholm Stock Exchange, but reported to the exchange by brokerage firms. This change in the registration arrangements meant that comparisons between pre- and post-1985 are not very relevant, and it naturally reduces the historical compatibility between the Nordic countries. Furthermore, comparisons between Swedish and Finnish figures in particular become skewed, since the reported turnover on the Finnish Stock Exchange is just a small fraction of the total turnover on the domestic Finnish bond market, as the table clearly shows.

The greatest problems in the reporting of turnover are found in Finland. On 1 August 1992, a primary dealer system was introduced to improve the liquidity and transparency of the secondary market. ${ }^{21}$ The main reason for this was the budget deficit that had started to grow in 1991. The substantial increase in 1992 and 1993 was then followed by a very low figure for 1994 (FIM 2.1 billion). The recorded drop is, however, deceptive. The falling turnover was mainly a consequence of a failed attempt to bring bond trading into the stock exchange. Since there were no binding regulations about reporting the trade in bonds, Finnish brokers simply stopped reporting their trade to the stock exchange. However, the Bank of Finland and the Primary 
Dealers (PD) then agreed that the PDs should report their transactions in Markka-denominated bonds (including government benchmark bonds).

Table 2 shows that despite the fall on the stock exchange, trade in bonds increased noticeably at the beginning of the 1990s, primarily because of growing budget deficits. At the end of the 1990's, a booming stock market and the liquidity issues related to Long Term Capital Management, concerns about $\mathrm{Y} 2 \mathrm{~K}$, and the introduction of the Euro led to more unstable liquidity conditions. This underscores how difficult it currently is to get a robust measure of developments in bond turnover. Given the growing importance now being shown to transparency in financial markets, it is likely that policy makers will need to develop some internationally comparable measure along the lines suggested here.

Not all jumps within the series depend on definitional changes. Table 2 also reveals some interesting features regarding the stability of turnover in the face of changing regulation. In Norway and Sweden turnover fell in 1988, while in Denmark in particular, and to some extent in Finland, it continued to rise in nominal values. However, when the Swedish turnover, for instance, is examined more closely it can be seen that the daily turnover in government bonds fell dramatically between 1987 and mid-1990. Between 1987 and 1989, turnover fell by as much as 40 per cent. The reason for the accelerated drop in 1989 was that a turnover tax on bonds was introduced in that year. That tax brought the forward market in bonds more or less to a standstill. After the tax was abolished in 1990, the market recovered. A dramatic increase then occurred in 1991, when turnover was more than twice as high as in 1989. Moreover some of the jumps may to some extent - as in the case of Norway 1998/99 - be explained by a more relaxed reporting attitude from one year to another by dealers in the system. 
Despite all these statistical problems, Table 3 suggests that, in relative terms, the turnover on Nordic bond markets increased as a share of GDP during the 1980s and 1990s, and peaked in the mid-1990s. Some of the decline in the late-1990's can be attributed to the introduction of the Euro, and the global effects of the LTCM crisis (BIS 1999; Persaud 2001).

As we have noted, liquidity measures express the risk of the non-completion of a transaction at a reasonable price, due to problems connected with the market rather than to problems connected with the bond as such. Hence, to be able to compare markets, we need measures of liquidity that are comparable across countries. Such measures are also required for assessing whether Nordic secondary markets meet international standards. Table 4 gives liquidity measures for the Nordic countries and for four other major national bond markets. None of the measurement problems mentioned above have disappeared, which means that the figures must be interpreted with caution. Thus, it needs to be remembered that substantial jumps in the series can often be explained by changes in the procedures for registration, listing or reporting, while downturns can be explained by the emergence of OTC markets with no equivalent reporting obligations. In most cases, the quality of reported figures very much hinges on the reporting discipline among market actors. A conclusion, based on our difficulty in finding good measures of liquidity, is that at the end of the 1990s most if not all markets can be said to possess a less than perfect transparency as regards static efficiency, especially in terms of the liquidity indicator. This is clearly highlighted in the large number of sources needed to compile Table 4.

Bearing all these measurement problems in mind a number of general points about liquidity on Nordic bond markets can be made. Table 4 indicates that historically Nordic bond markets have had a significantly lower level of liquidity than that of the major international markets. In 1990, bonds on the Nordic markets were sold on average about once a year, while turnover of 
bonds in the US occurred about twelve times per year and in the UK bond turnover occurred about eight times. Of the Nordic countries, Denmark had the most liquid market. However, the figures should be used with caution. The liquidity measures for Finland presented in the table are based on the sum of the turnover on the exchange and on the OTC market. ${ }^{22}$ In a similar vein, to demonstrate the vulnerability of the liquidity measures to differences in coverage, consider an example from the Swedish market. To indicate the dependence of the indicator on the definition, if only trading in bonds covered by the daily list - the list of the most traded bonds - is included, then the liquidity measure for 1990 would have been a little over twice the stock.

Many of the measurement problems discussed above are equally relevant in connection with our international figures. If we study the liquidity of the New York Stock Exchange alone, for instance, we would get a very low liquidity measure, which in turn would imply that only a small fraction of the stock of US treasury notes and bonds is traded each year. The same observation can be made regarding the Japanese market, where large-lot OTC trading between banks accounts for about 95 per cent of total turnover in the bond market. When it comes to inconsistencies over time, however, not all jumps, despite the warnings above, indicate the problems we have noted. For example, the jump in the US measure from 1980 to 1985 was caused by efforts on the part of the US Treasury to stimulate the market by, among other things, the abolition of a withholding tax in 1984. Similarly, the dramatic increase in the liquidity of the Japanese market between 1980 and 1985 has at least in part a policy-derived explanation: from 1984, banks in Japan were permitted to act as dealers in the OTC market.

Gallant (1988) provides an alternative estimate of the liquidity of non-Nordic markets for 1986. He estimated that turnover of the German, Japanese, UK and US domestic bond markets at 7, 5, 9, and 12 times the stock respectively. When Gallant's figures are compared with those in Table 5, a 
large discrepancy appears between the two measures for the German market. However, had we measured the liquidity of Bundesrepublikanleihe only, we would have also obtained a similar result. Further, following the liberalization of 1984-86, the market was hit by a 10 per cent withholding tax during 1988 and 1989. As regards the deviation between Gallant's figures and ours for the UK market, a plausible explanation could be found in the Big Bang of 1986, which quadrupled turnover.

Towards the end of the 1990s, the US treasury bond market reached a turnover corresponding to 16 times the outstanding stock at par value maintaining its global position as the number one market in terms of liquidity. During the 1990s all the Nordic markets recorded quite large increases in liquidity, with the Swedish market emerging at the end of the decade as the most liquid market with an annual turnover corresponding to four times the outstanding stock. Regardless the improvements in this respect, a transparency problem remains when it comes to both international as well as inter-temporal (vulnerability) comparisons. This recurring issue of transparency is taken up again in the concluding section.

\section{Concluding remarks on the efficiency of secondary bond markets}

This paper has explored a supplementary approach to market efficiency. It has developed that approach through the notion of static market efficiency, a qualitative concept that is closer to the concept of allocative/resource efficiency usually understood by economists. These concepts of efficiency are receiving growing interest in recent research (Rajan and Zingales 1998; Wurgler 2000). One of the problems confronting researchers attempting to employ such concepts is finding relevant measures of economic efficiency. Developing such measures remains a work in progress. The paper proposed a concept of static efficiency to capture aspects of economic efficiency that informational efficiency does not. The indicators are developed in a way that allows the most relevant international and inter-temporal comparisons. No single measure of static efficiency was 
advanced; rather, four indicators were suggested. They were the degree of transparency, number of maturities and issuers, spread, and liquidity.

At the end of the 1990s, the results as regards of the static efficiency indicators for bond markets in the Nordic region all point in the same direction. The markets have improved considerably over recent years and are now only slightly less efficient than the major bond markets in key financial centres. However, for all the Nordic markets transparency has been and remains a problem, and this makes all qualitative concepts difficult to operationalise. We suggest that the four indicators of market quality could form the basis of standard international disclosure practice for bond markets given suitable reporting by market participants.

The concept of static efficiency may be usefully applied in several areas of financial research, including for instance addressing questions of how leading financial centres gain and maintain leadership, how OTC markets have emerged as leading ways of undertaking financial transactions, and even perhaps as a vehicle for exploring the growing role of derivatives transactions in financial markets. An even more relevant area of possible application concerns the issue of investor protection. While debate is ongoing about the legal bases for investor protection, information on static efficiency of markets has received less attention and yet as far as day-to-day monitoring is concerned, static efficiency indicators can be extremely useful. This is especially important in the so-called transition and emerging economies where the related issues of markets as institutions and investor protection are now pervasive (World Bank 2001). The use of static efficiency indicators could also be very helpful in benchmarking activities of financial markets in for instance the EU accession process. Furthermore, with proposals to use subordinated debt as part of future bank regulation, market participants will need much better information about how such debt markets function. 
The concept of static efficiency developed here can be usefully extended in two ways. Firstly, the concept of static market efficiency could be made more comprehensive by broadening the measure of liquidity to capture not only depth but also width, immediacy, and resilience. This could include for instance attempting to find further indicators of liquidity such as the average number of bonds traded at a given bid-ask quote, the speed at which trades of a given size can be executed and price reversion after order flow imbalances, as well as evidence of price clustering (Harris 1990; Gwilyam et.al. 1998). Static efficiency measures of liquidity could also be extended to include minimum tick size, as well as trading and issue costs, which are known to affect liquidity and efficient price discovery (Ball and Chordia 2001). ${ }^{23}$

One of the main issues to emerge from the study is the problem of transparency. The difficulty in finding good measures of liquidity reveal just how far we have to go in improving transparency in all four Nordic markets. Yet data problems alone should not deter us from exploring financial markets in ways that reveal additional insights to existing analysis. As transparency has itself moved to centre stage in global concerns following the Asian financial crisis, and the accounting and investment banking scandals on Wall Street, the problem of trying to understand (and provide measures to aid) transparency will be ongoing. Indeed, the data problem of measuring liquidity is not restricted to particular regional markets, be they Nordic or Asian; it is a global problem. We suggest that there is a need for more consistent and relevant measures of liquidity in order to make international comparisons more informative. A good start would be to establish an international standard base for measuring numerator and denominator in liquidity along the lines outlined here. 
Table 1 Registration and reporting requirements on the Nordic bond markets

\begin{tabular}{|c|c|c|c|c|c|c|c|c|}
\hline & \multicolumn{2}{|r|}{ Denmark } & \multicolumn{2}{|r|}{ Finland } & \multicolumn{2}{|c|}{ Norway } & \multicolumn{2}{|c|}{ Sweden } \\
\hline & $\begin{array}{l}\text { Date of } \\
\text { introduction }\end{array}$ & Regulated by: & $\begin{array}{l}\text { Date of } \\
\text { introduction }\end{array}$ & Regulated by: & $\begin{array}{l}\text { Date of } \\
\text { introduction }\end{array}$ & $\begin{array}{l}\text { Regulated } \\
\text { by: }\end{array}$ & $\begin{array}{l}\text { Date of } \\
\text { introduction }\end{array}$ & $\begin{array}{l}\text { Regulated } \\
\text { by: }\end{array}$ \\
\hline $\begin{array}{l}\text { Registration } \\
\text { of bonds }\end{array}$ & 4 October 1982 & $\begin{array}{l}\text { The Securities Centre Act of } \\
16 \text { January } 1991\end{array}$ & $\mid \begin{array}{l}1942 \\
1 \text { January } 1970 \\
1 \text { January } 1994\end{array}$ & $\left\{\begin{array}{l}\text { Act on Bonds }{ }^{\mathrm{a}} \\
\\
\text { Act on Bonds and } \\
\text { Debentures and Other } \\
\text { Collective Debt Securi- } \\
\text { ties } \\
\hdashline--1- \\
\text { Securities Market Act }\end{array}\right.$ & $\begin{array}{l}\text { No obligation to } \\
\text { register prior to the } \\
\text { introduction of } \\
\text { VPS (Verdipapir- } \\
\text { central) in } 1986\end{array}$ & $\begin{array}{l}\text { Securities } \\
\text { Registry Act } \\
\text { of } 1985 .\end{array}$ & 1863 & $\begin{array}{l}\text { Stock } \\
\text { Exchange } \\
\text { Regulation }\end{array}$ \\
\hline $\begin{array}{l}\text { Listing of } \\
\text { bonds }\end{array}$ & $\begin{array}{l}10 \text { November } \\
1983\end{array}$ & $\begin{array}{l}\text { Order on conditions of the } \\
\text { admission of the Securities } \\
\text { to Official Listing on the } \\
\text { Copenhagen Stock } \\
\text { Exchange, No. } 418 \text { of } 31 \\
\text { May } 1991\end{array}$ & 1 August 1989 & $\begin{array}{l}\text { Securities Market Act. } \\
\text { Stock exchange regula- } \\
\text { tion regulates the trading } \\
\text { of shares and debt } \\
\text { instruments }\end{array}$ & January 1981 & $\begin{array}{l}\text { Issuing } \\
\text { control }\end{array}$ & 1863 & $\begin{array}{l}\text { Stock } \\
\text { Exchange } \\
\text { Regulation }\end{array}$ \\
\hline $\begin{array}{l}\text { Reporting of } \\
\text { trade in } \\
\text { bonds }\end{array}$ & $\begin{array}{l}\text { 4 September } \\
1987\end{array}$ & $\begin{array}{l}\text { Act on Copenhagen Stock } \\
\text { Exchange, Consolidated Act } \\
\text { No. } 26 \text { of } 15 \text { January } 1982\end{array}$ & 1 October 1996 & $\begin{array}{l}\text { Securities Market Act. } \\
\text { Act on the Financial } \\
\text { Supervision Authority }\end{array}$ & May 1981 & $\begin{array}{l}\text { The Stock } \\
\text { Exchange } \\
\text { Act }\end{array}$ & $\begin{array}{l}1985 \\
\\
30 \text { March } \\
1987 \\
\\
13 \text { June } 1991\end{array}$ & $\begin{array}{l}\text { Voluntary } \\
\text { Riksbanken } \\
\text { Securities } \\
\text { Market Act }\end{array}$ \\
\hline $\begin{array}{l}\text { Withholding } \\
\text { tax }\end{array}$ & No tax & & January 1991 & Withholding Tax Law & No tax & & No tax & \\
\hline $\begin{array}{l}\text { Book-entry } \\
\text { securities }\end{array}$ & January 1983 & $\begin{array}{l}\text { The Securities Centre Act of } \\
16 \text { January } 1991\end{array}$ & August 1991 & $\begin{array}{l}\text { Law on Book Entry } \\
\text { Securities }\end{array}$ & 1986 & $\begin{array}{l}\text { Securities } \\
\text { Registry Act } \\
\text { of } 1985\end{array}$ & $\begin{array}{l}\text { September } \\
1993\end{array}$ & $\begin{array}{l}\text { VPC; by } \\
\text { agreement }\end{array}$ \\
\hline
\end{tabular}

${ }^{a}$ The first Act on Bonds came into force in 1942, but registration was not made compulsory until the 1970 Act. 
Table 2 Annual reported bond turnover, 1971-2002

(Billions of US dollar, nominal values, spot, end-of period exchange rates)

\begin{tabular}{|c|c|c|c|c|c|}
\hline & Denmark & & & Norway & Sweden $^{b}$ \\
\hline & Stock Exchange & Stock Exchange & $\mathrm{OTC}^{\mathrm{g}}$ & Stock Exchange & Stock Exchange \\
\hline 1971 & na & 0.01 & & 0.25 & 0.04 \\
\hline 1972 & na & 0.10 & & 0.32 & 0.06 \\
\hline 1973 & na & 0.01 & & 0.33 & 0.09 \\
\hline 1974 & na & 0.01 & & 0.54 & 0.12 \\
\hline 1975 & na & 0.01 & & 0.81 & 0.18 \\
\hline 1976 & na & 0.01 & & 0.81 & 0.27 \\
\hline 1977 & na & 0.02 & & 1.17 & 0.36 \\
\hline 1978 & na & 0.04 & & 0.60 & 0.72 \\
\hline 1979 & na & 0.07 & & 0.61 & 1.21 \\
\hline 1980 & 3.69 & 0.09 & & 1.70 & 2.15 \\
\hline 1981 & 3.32 & 0.25 & & 1.29 & 1.20 \\
\hline 1982 & 3.08 & 0.45 & & 0.67 & 1.03 \\
\hline 1983 & 6.08 & 0.41 & & 0.75 & 1.29 \\
\hline 1984 & 4.80 & 0.77 & & 2.24 & $1.11^{\mathrm{d}}$ \\
\hline 1985 & 8.80 & 1.66 & & 10 & $164^{\mathrm{c}}$ \\
\hline 1986 & 14 & 1.36 & & 11 & 175 \\
\hline 1987 & 17 & 1.17 & & 21 & 233 \\
\hline 1988 & $144^{\mathrm{a}}$ & 1.37 & & 15 & 164 \\
\hline 1989 & 273 & 1.82 & 3.99 & $27^{\mathrm{e}}$ & $131^{\mathrm{f}}$ \\
\hline 1990 & 341 & 1.27 & 3.16 & 50 & 182 \\
\hline 1991 & 370 & 0.24 & 7.90 & 71 & 339 \\
\hline 1992 & 797 & 2.94 & 15 & 72 & 420 \\
\hline 1993 & 1662 & 10 & 50 & 211 & 642 \\
\hline 1994 & $1081^{\mathrm{h}}$ & 0.44 & 110 & 226 & 1040 \\
\hline 1995 & 1079 & 0.25 & 129 & 277 & 972 \\
\hline 1996 & 1120 & 0.11 & 148 & 392 & 1488 \\
\hline 1997 & 1001 & 0.09 & 153 & 472 & 1721 \\
\hline 1998 & 1276 & 0.08 & 165 & 474 & 1621 \\
\hline 1999 & 967 & 0.00 & 112 & 97 & 1535 \\
\hline 2000 & 692 & 0.01 & 87 & 84 & 783 \\
\hline 2001 & 661 & 0.01 & 75 & 78 & 644 \\
\hline 2002 & 834 & 0.02 & 87 & 106 & 728 \\
\hline
\end{tabular}

${ }^{a}$ An electronic trading system was introduced in September 1987 with limited availability. By 1988, stockbroker companies could trade on the system from their own offices.

${ }^{\mathrm{b}}$ Including premium bonds

${ }^{\mathrm{c}}$ A new registration system was introduced in 1985/86

${ }^{\mathrm{d}} \mathrm{Up}$ to 1984 predominantly premium bonds (SEK 160 million interest-bearing bonds)

eAn electronic trading system, decentralized to the brokers' offices, was introduced.

${ }^{\mathrm{f}}$ An electronic trading system called SAX (Stockholm Automated Exchange) was introduced.

${ }^{\mathrm{g}}$ Consisting of reported transactions in all Finnish Markka-denominated bonds (bank bonds, corporate bonds and government bonds).

${ }^{\mathrm{h}}$ A new registration system. Figure including repurchase agreements is DKK 16207.1 billion.

Sources: Based on data from Copenhagen Stock Exchange, Database; Helsinki Stock Exchange, Database; Bank of Finland, Financial Markets, Statistical Review, various issues; Oslo Stock Exchange, Database; and Stockholm Stock Exchange, Annual report, various issues. Copenhagen Stock Exchange Factbooks various issues, Stockholm Stock Exchange Factbooks various issues, Bank of Finland, Statistical Review, various issues. 
Table 3 Annual bond turnover on the Nordic stock exchanges, 1975-2000 Percentage of GDP

\begin{tabular}{lccrrrr}
\hline Country & $\mathbf{1 9 7 5}$ & $\mathbf{1 9 8 0}$ & $\mathbf{1 9 8 5}$ & $\mathbf{1 9 9 0}$ & $\mathbf{1 9 9 5}$ & $\mathbf{2 0 0 0}$ \\
\hline Denmark & na & 6 & 13 & 246 & 593 & 433 \\
Finland & 0 & 0 & 3 & 1 & 100 & 72 \\
Norway & 3 & 3 & 15 & 45 & 189 & 50 \\
Sweden & 0 & 2 & 138 & 76 & 378 & 345 \\
\hline
\end{tabular}

Sources: Based on data from Copenhagen Stock Exchange, Database; Central Statistical Bureau of Denmark; Helsinki Stock Exchange, Database; Bank of Finland; Oslo Stock Exchange, Database; Central Statistical Bureau of Norway; Stockholm Stock Exchange, Annual report, various issues; Central Statistical Bureau of Sweden; and Nordic Statistical Secretariat, Yearbook of Nordic Statistics, various issues; OECD, National Accounts, Vol. 1, 1994. 
Table 4 Liquidity of national bond markets 1975 - 2000

Annual turnover as a percentage of outstanding stock at par value

\begin{tabular}{lrrrrrr}
\hline Country & $\mathbf{1 9 7 5}$ & $\mathbf{1 9 8 0}$ & $\mathbf{1 9 8 5}$ & $\mathbf{1 9 9 0}$ & $\mathbf{1 9 9 5}$ & $\mathbf{2 0 0 0}$ \\
\hline Denmark $^{\mathrm{b}}$ & na & 5 & 8 & 153 & 320 & 273 \\
Finland $^{\mathrm{c}}$ & 0 & 2 & 15 & 33 & 241 & 185 \\
Norway $^{\mathrm{d}}$ & 36 & 21 & 60 & 107 & 417 & 182 \\
Sweden $^{\mathrm{e}}$ & 0 & 3 & 188 & 104 & 577 & 397 \\
\hline Germany $^{\mathrm{f}}$ & na & na & 21 & 62 & 226 & $146^{\mathrm{j}}$ \\
Japan $^{\mathrm{g}}$ & na & 60 & 561 & 417 & 885 & $778^{\mathrm{j}}$ \\
United Kingdom $^{\mathrm{h}}$ & 192 & 214 & 218 & 769 & 624 & $621^{\mathrm{j}}$ \\
United States $^{\mathrm{i}}$ & 286 & 438 & 1087 & 1202 & 1411 & $1626^{\mathrm{k}}$ \\
& & & & & & \\
\hline
\end{tabular}

${ }^{a}$ Turnover in derivatives not included.

${ }^{\mathrm{b}}$ Annual turnover on the Copenhagen Stock Exchange as a percentage of outstanding stock of listed bonds. Traded on the exchange are government, mortgage, special institution, convertible, index-linked and foreign bonds.

${ }^{\mathrm{c}}$ Annual turnover on the Helsinki Stock Exchange and over the counter as a percentage of outstanding stock of listed bonds.

${ }^{\mathrm{d}}$ Annual turnover registered on the Oslo Stock Exchange as a percentage of outstanding stock of listed bonds. Traded on the exchange are government, government-guaranteed, government premium, municipality/county guaranteed, bank, insurance, mortgage bank, industrial and foreign bonds.

${ }^{\mathrm{e}}$ Annual turnover on the Stockholm Stock Exchange as a percentage of outstanding stock of listed bonds. Traded on the exchange are government, government premium, mortgage, municipality, bank, industry, utility, ship, convertible and foreign bonds.

${ }^{\mathrm{f}}$ Annual turnover on the German Stock Exchanges as a percentage of outstanding stock of listed bonds.

${ }^{\mathrm{g}}$ Annual turnover in public and corporate bonds as a percentage of outstanding stock of bonds in Japan, where bonds held by government agencies, Bank of Japan, Postal Annuity, Postal Life Insurance and Trust Fund Bureau are excluded.

${ }^{\mathrm{h}}$ Annual turnover of gilt-edged bonds on stock exchanges as a percentage of outstanding stock of gilts. Note that the figures include gilts with maturities of less than one year.

${ }^{\mathrm{i}}$ Annual turnover of US Treasury notes and bonds as a percentage of outstanding stock of US treasury notes and bonds.

j 1998.

k 1999.

Sources: Based on data from: Copenhagen Stock Exchange, Database, Factbook and Annual Report; Central Statistical Bureau of Denmark, Statistical Yearbook, various issues; Helsinki Stock Exchange, Database; Central Statistical Bureau of Finland, Financial Market Statistics, various issues; Bank of Finland, Statistical Overview, Oslo Stock Exchange, Database and Annual Report; Central Statistical Bureau of Norway, Credit market statistics and Bank- Kredittstatistikk, various issues; Stockholm Stock Exchange Factbook, various issues, Annual report, various issues; Central Statistical Bureau of Sweden, Database; BIS, (1992b); German Stock Exchange, Database; Factbook, various issues Central Statistical Office of UK, Financial Statistics, various issues; Debt management office, Database, Gilt Review; US Government, Economic Report of the President, 1992; Federal Reserve, Federal Reserve Bulletin, various issues; Quarterly Primary Dealer Report, various issues, The Bureau of Public Debt, Monthly Statement of the Public debt of the United States, (Dec.2000) NYSE, Fact Book, various years, FIBV, Annual Statistics, various years; and own estimates. 


\section{Bibliography}

Ball, C., Chordia, T., 2001. True Spreads and Equilibrium Prices. Journal of Finance 56 (5), 18011835.

Bank for International Settlements (BIS), 1999. Market Liquidity: Research Findings and Selected Policy Implications. BIS Basle.

Bloomfield, R., O’Hara, M., 1999. Market Transparency: who wins and who loses? Review of Financial Studies 12, 5-35.

Boudoukh, J., Whitelaw, R., 1993. Liquidity as a Choice Variable: a lesson from the Japanese government bond market. Review of Financial Studies 6, 265-292.

Burns, J., 1979. A treatise on markets: spot, futures, and options. American Enterprise Institute for Public Policy Research, Washington.

Chakravarty, S., Sarkar, A., 1999. Liquidity in US fixed income markets: A comparison of the bid-ask spread in corporate, government and municipal bond markets. Working paper, Federal Reserve Bank of New York.

Chan, K., Hwang, C., 1998. The impact of tick size on market quality: An empirical investigation of the stock exchange of Hong Kong. Working paper, Hong Kong University.

Chordia, T., Sarkar, A., Subrahmnanyam, A. 2003. An Empirical Analysis of Bond Market Liquidity. Federal Reserve Bank of New York Staff Reports No 164, March.

Gallant, P., 1988. The Eurobond Market. Woodhead Faulkner.

Goodhart, C., O'Hara, M., 1997. High frequency data in financial markets: Issues and applications. Journal of Empirical Finance 4, 73-114.

Grossman, S., Stiglitz, J., 1980. On the Impossibility of Informationally Efficient Markets. American Economic Review 74(4), September. 
Gwilyam, O., Clare, A., Thomas, S., 1998. Price Clustering and bid-ask spreads in international bond markets. Journal Of International Financial Markets, Institutions and Money 8, 377 391.

Harris, L., 1990. Liquidity, Trading Rules, and Electronic Trading Systems. NYU Salomon Centre, Monograph Series in Finance and Economics, 1990-4.

Hotchkiss, E., Ronen, T., 2002, The Informational Efficiency of the Corporate Bond Market: An Intraday Analysis. Review of Financial Studies 15, 1325-1354.

Housbrouck, J, 1993. Assessing the Quality of a Security Market: a new approach to transactioncost measurement. A Review of Financial Studies 6, 1, 191-212.

Huang, R., Stoll, H, 2001. Tick Size, Bid-Ask Spreads and Market Structure. Journal of Financial and Quantitative Analysis 36, Dec, 503-522.

Innoue, H 1999. The Structure of Government Securities Markets in G10 Countries: Summary of Questionnaire Results in BIS Market Liquidity: Research Findings and Selected Policy Implications. BIS, Basle.

Koskinen, Y., Pylkkönen, P., 1992. The Bond Market in Finland, Bank of Finland Bulletin 6-7.

LaPorta, R, Lopez-de-Silanes, F., Shleifer, A., Vishny, R., 2000. Investor Protection and Corporate Governance. Journal of Financial Economics 58 (1-2), 3-27.

McCauley, R., Remolana, E., 2000. Size and Liquidity of Government Bond Markets. BIS Quarterly Review, November, 52-60.

Mares, A., 2002. Market Liquidity and the Role of Public Policy. BIS Papers No 12, 18, 385-401.

O’Hara, M., 2001. Overview: market structure issues in market liquidity, in Market Liquidity: proceedings of a workshop held at the BIS. BIS Basle, April, 1-8.

Oxelheim, L., 1996. Financial Markets in Transition - Globalization, Investment and Economic Growth. Routledge, London. 
Oxelheim, L., Rafferty, M., 2001. On the Static Efficiency of Secondary Bond Markets. WP2001/7, Lund Institute of Economic Research, Lund University, Lund.

Oxelheim, L., Rafferty, M., 2003. Dynamic Efficiency of Secondary Bond Markets. WP2003/4, Lund Institute of Economic Research, Lund University, Lund.

Pagano, M., Röell, A., 1996. Transparency and Liquidity: A Comparison of Auction and Dealer Markets with Informed Trading. Journal of Finance 51, 579-612.

Persaud, A. 2001. The Puzzling Decline in Financial Market Liquidity: proceedings of a workshop held at the BIS, BIS, Basel, April, 152-158.

Rajan, R., Zingales, L., 1998. Financial Dependence and Growth. American Economic Review, 88, June, 559-586.

Rantalainen, K., 1993. The Primary Dealer System in Finland. Bank of Finland Bulletin, No. 2.

Sarig, O., Warga, A., 1989. Some Empirical Estimates of the Risk Structure of Interest Rates. .Journal of Finance, 44 (5), December: 1351-60.

Stiglitz, J., 1981. The Allocational Role of the Stock Market: Pareto Optimality and Competition. Journal of Finance 36 (2): 235-251.

Theissen, E., 1998. Market Structure, Informational Efficiency and Liquidity: An Experimental Comparison of Auction and Dealer Markets. Working paper Johan Wolfgang Goethe Universität.

World Bank, 2001. World Development Report 2002 - Building Institutions for Markets. World Bank Washington DC.

Wurgler, J., 2000. Financial Markets and the Allocation of Capital. Journal of Financial Economics 58, 187-214.

\section{Acknowledgements}

We wish to thank the editor and an anonymous reviewer for helpful comments and suggestions on an earlier draft and Göran Zakrisson, Spintab. 
${ }^{1}$ Supply in a bond market is in part a function of the net finance requirements of the borrower. Demand for bonds, on the other hand, has many determinants.

${ }^{2}$ Here, market efficiency may be thought of as being the output of financial intermediation (c.f. Mares 2002).

${ }^{3}$ Hotchkiss and Ronen (2002), following Hasbrouk (1993), use an estimate of pricing error as a measure of market quality. In these studies, market quality is therefore a component of informational efficiency.

${ }^{4}$ Formerly, the Association of International Bond Dealers (AIBD)

${ }^{5}$ Euroclear was launched in 1968 by Morgan Guaranty, while its major competitor, Clearstream (formerly Cedel), was founded in 1970. Both act as clearing houses for bonds and equities.

${ }^{6}$ For example, Pagano and Röell (1996).

${ }^{7}$ It is recognized that a trade-off must sometimes be made between transparency, or what Harris (1996) termed the display of liquidity and attracting liquidity. As he put it, 'Trading systems that force traders to expose their standing orders may drive those orders away'. See also Bloomfield and O'Hara (1999).

${ }^{8}$ Based on FIBV statistics (1991).

${ }^{9}$ A further issue relating to listing practices concerns the issue of the minimum face value of bonds. This is a quite complex issue because they have historically varied within markets. For instance, in the Stockholm SOX it is SEK 10 000, whereas in the professional market it is more like SEK 25000 000. At the Copenhagen Stock Exchange the minimum face value is DKK 1000, at the Oslo Stock Exchange NOK 1000 and at the Helsinki Stock Exchange Euro 1000. Hence, there are considerable differences between markets as well. What seems to matter more then is the trading habits and culture, as well as the unit of trading. The minimum face value issue is of central interest in the recent EU prospectus directive. The directive says that for a bond of a minimum nominal value of Euro 50000 there is no need to present a complete prospectus since such an issue is not assumed to target private investors. Despite this recent interest, we argue that the emergence of bonds in a dematerialized system will reduce the importance of this issue over time.

${ }^{10}$ Helsinki interbank offered rate and (from 1999) Euribor.

${ }^{11}$ Innoue 1999; and McCauley and Remolana 2000 discuss the trade-off between a few (liquid) benchmark issues and supplying a continuous yield curve (fragmentation).

${ }^{12}$ In 2000, foreign bond listing constituted 2 percent of all listings at the Copenhagen Stock Exchange. At the Oslo Stock Exchange and the Stockholm Stock Exchange the foreign listing amounted to 0.5 and 1 percent, whereas in Finland there was no foreign bond listed. However, the amounts raised by foreigners in the domestic market are in most cases hard to single out (FIBV).

${ }^{13}$ Spread refers here to the difference between the bid and offer price in the quotation of a bond. Another kind of spread, or margin, relevant here is the difference between the offered prices of two different bonds, in particular the difference between the government rate, as some kind of benchmark rate without credit risk, and rates on other kinds of bonds. In this case, spread will include credit risk and differences in liquidity premiums as well.

${ }^{14} \mathrm{~J}$ P Morgan used to publish a series disaggregating bond market segments into the 'traded', 'active' and 'benchmark' sectors. Data was reported by the Bank for International Settlements in 1999, but without a comparable base. For a comparison of disaggregated bond spread data in the early 1990's, see Oxelheim and Rafferty (2001).

${ }^{15}$ Liquidity is an expression of the ability to deal in reasonable amounts at the current market prices. In general, the more recent the individual issue, the more liquid it is. After a while, bonds tend to settle into the hands of institutional investors who plan to hold them until maturity. 
${ }^{16}$ For a discussion of the definition of tightness, resiliency and depth, see BIS (1999).

${ }^{17}$ On the related issue of the macro and micro determinants of liquidity see Chordia et.al. (2002).

${ }^{18}$ Unlike in the case of the shares, this proxy may be good as long as the use of zero-coupon bonds is not large.

${ }^{19}$ Forward transactions are sometimes quite large. At the beginning of the 1990s, the forward trade in treasury bonds on the Swedish bond market, for instance, was only slightly smaller than the spot trade.

${ }^{20}$ FIBV makes a distinction between REV (indicating that all transactions are reported, like in Norway, Sweden and the UK) and TEV (indicating that only transactions in the system of the stock exchange are reported, like in Germany, Japan and the US).

${ }^{21}$ See Rantalainen (1993) on the primary dealer system and Koskinen and Pylkkönen (1992) on the bond market.

${ }^{22}$ To make the point more clearly, in 1990, bond turnover on the Helsinki stock exchange amounted to FIM 4.6 billion, while on the OTC market it was FIM 11.5 billion. However, even here there was no mandatory reporting requirement, so OTC turnover may have been underestimated.

${ }^{23}$ However, according to Huang and Stoll (2001), many characteristics are endogenous to market structure. The London dealer market, for instance, has no mandated tick size, and exhibits higher spreads and price clustering, but higher depth than the NYSE auction market. For the purpose of static efficiency indicators, tick size is therefore best understood as part of the spread, and thus its effect on quality is part of the interaction between spread and liquidity. 